\title{
1. DICOTOMIAS LINGUÍSTICAS E JURÍDICAS E ARBITRARIEDADE EM “ANTÍGONA” DE SÓFOCLES: ALGUMAS ANÁLISES E APROXIMAÇÕES
}

\section{LINGUISTICS AND LEGAL DICHOTOMIES AND ARBITRARINESS IN “ANTIGONE” BY SOPHOCLES: SOME ANALYZES AND APPROACHES}

\author{
Dartagnan Ferrer dos Santos ${ }^{1}$ \\ Celso Augusto Nunes da Conceição ${ }^{2}$ \\ "A única coisa que torna poderoso aquele que manda é a obediência \\ daquele que obedece." Schiller
}

\begin{abstract}
Resumo: Busca-se com este artigo usar a peça "Antígona" de Sófocles para um estudo básico de algumas consagradas dicotomias linguísticas e jurídicas. Assim, no campo linguístico serão analisados os binômios "língua $x$ fala" e "competência $x$ desempenho", enquanto na seara jurídica se examinará as oposições entre "direito natural x direito positivo" e "direito universal x direito local". Posteriormente, na medida do possível, serão aproximadas as relações entra essas duas áreas e se oferecerá uma analogia conceitual acerca das arbitrariedades linguística e jurídica, alicerçando-a na obra clássica.
\end{abstract}

Palavras-chaves: dicotomias, linguística, direito, arbitrariedade.

\begin{abstract}
This article intends to use the play "Antigone " by Sophocles for a basic study of some consecrated linguistic and legal dichotomies. Thus, in the former field the binomials "language $\mathrm{x}$ speak" and "competence $\mathrm{x}$ performance" will be analyzed, just like will be the oppositions between "natural law x positive law" and "universal law x local law" in the legal area. Later, as far as possible, these two areas will be approximated and a conceptual analogy about the linguistic and legal arbitrariness basing it on the classic work will be offer.
\end{abstract}

Keywords: dichotomies , linguistics, law, arbitrarines

\footnotetext{
${ }^{1}$ Mestre em Direito. Professor do Curso de Direito da Faculdade Inedi, Cesuca. Advogado. E-mail: dartagnansantos@cesuca.edu.br.

2 Professor das disciplinas de Português Jurídico e Direito e Linguagem no Cesuca, Mestre e Doutor em Linguística Aplicada na PUCRS. E-mail: celsus@terra.com.br.
} 
Sumário: Introdução; 2. Duas dicotomias linguísticas; 3. Duas dicotomias jurídicas; 4. Cotejamento dicotômico linguístico-jurídico: arbitrariedade e mutabilidade; Considerações finais: atualidade da "arbitrariedade" linguística e jurídica na fala de Creonte; Referências bibliográficas

\section{INTRODUÇÃO}

A pretensão deste estudo é utilizar alguns dos principais diálogos do drama "Antígona" de Sófocles para se chegar a um exame inicial de algumas consagradas dicotomias $^{3}$ linguísticas e jurídicas estabelecendo-se relações entre elas. Desse modo, em um primeiro momento, no campo da linguística se examinará os binômios "língua/fala" e “competência/desempenho", traçando as características básicas dessas oposições e já ensaiando-se as primeiras aproximações com o jurídico; depois, na âmbito da teoria geral do direito serão analisadas as oposições entre "direito natural/direito positivo" e "direito universal/direito local", lembrando-se ainda uma particularidade da oposição entre direito "público/privado" no âmbito do direito do trabalho.

Como método de escrita utilizou-se principalmente a pesquisa bibliográfica, inclusive apresentando-se algumas notícias e questões muito atuais que comportam as análises apresentadas. Com teor introdutório, o estudo é direcionado principalmente aos estudantes de graduação, a fim de que esses tomem contato e/ou aprimorem seu conhecimento a respeito dos tópicos apresentados bem como aprofundem sua capacidade de estabelecer relações entre a literatura, a linguística e o direito, três campos do saber que podem ser estudados de maneira interdisciplinar com resultados admiráveis, buscando-se com esse diálogo a melhor construção do saber e mesmo "de uma sociedade mais ética e democrática". ${ }^{4}$

Após suficientemente apresentadas as referidas dicotomias linguísticas e jurídicas, se pretende aproximar um pouco mais as relações estabelecidas no âmbito dessas duas áreas do

3 JAPIASSÚ, Hilton e MARCONDES, Danilo. Dicionário básico de filosofia. 4. ed. atual. Rio de Janeiro. Editora Zahar, 2006, p. 74. "Dicotomia" é a "divisão de uma classe de fenômenos em duas partes, cujas diferenças são contraditórias".

4 ALVES, Elizete Lanzoni. A interdisciplinaridade no ensino jurídico: construção de uma proposta pedagógica. In: O ensino jurídico interdisciplinar: um novo horizonte para o direito. MONDARDO, Dilsa, ALVES, Elizete Lanzoni e SANTOS, Sidney Francisco Reis dos (Orgs.). Florianópolis. OAB/SC Editora, 2005, p. 38-9. 
saber. Nesse momento, toma-se como suficiente para tal a análise dos conceitos de "arbitrariedade" e "mutabilidade", os quais são seminais tanto para o debate entre Creonte e Antígona, como para a estrutura da linguística e do direito. Tudo para, ao final, voltando-se novamente a uma analogia com a obra clássica, deixar-se em aberto pelo menos algumas questões que emergem deste estudo.

\section{DUAS DICOTOMIAS LINGUÍSTICAS}

A retrospectiva linguística remonta a época em que "Antígona" foi escrita por Sófocles e "Crátilo" surgiu como um dos tantos "Diálogos de Platão". ${ }^{5}$ Assim, ambas as obras que remontam há cerca de três séculos antes de Cristo são aqui apresentadas com o propósito de dar visibilidade às bases conceituais sobre a origem da linguagem, principalmente no que tange às duas dicotomias que são objeto desse estudo.

"Crátilo" apresenta três personagens discutindo sobre a natureza dos nomes: Crátilo, Hermógenes e Sócrates. O primeiro argumenta que os nomes correspondem à natureza das coisas que os designam, na sua essência; o segundo sustenta que há um "legislador" que atribui nomes às coisas. E Sócrates entra como intermediador ouvindo o que cada um tem a dizer. Em um primeiro momento, aceita os argumentos de ambos, mas em seguida faz oposições, criando assim mais problema e parecendo não se posicionar a respeito. $\mathrm{Na}$ verdade, os dois estavam certos naquilo que estavam defendendo: Crátilo, ao se posicionar pelo natureza dos nomes, estava falando de linguagem; Hermógenes, argumentando pela nominalização, caracteriza-se pelo convencionalismo. Língua é convenção e toda convenção é mutável.

Um salto no tempo para o famoso "Debate da Tábula Rasa" do Século XVII, em que Leibniz e Locke discutem se a linguagem é inata ou adquirida. Foi a grande questão da dicotomia que ainda hoje se discute: Linguagem e Pensamento. Na verdade, eles retomam Platão - pela corrente do Naturalismo/Mentalismo - e Aristóteles pelo Convencionalismo. Para Platão, as ideias já estão no cérebro e são inatas. Leibniz o retoma dizendo: "são

5 PLATÃO. Diálogos VI: Crátilo, Cármides, Láques, Ion, Menexeno. São Paulo: Edipro, 2010. 
representações que estão na alma antes de qualquer impressão pelos sentidos e são eles que podem atualizá-las", ou seja, as ideias são inatas e são as que permitem a aquisição de conhecimento e a subjetividade humana. Por outro lado, vem Locke com sua afirmação de que o conhecimento só pode ser adquirido pela experiência, ${ }^{6}$ retomando assim Aristóteles, que disse "não existe nada no espírito humano que antes não tenha passado pelos sentidos". Assim, no diálogo, Crátilo está para Platão e Leibniz, assim como Hermógenes para Aristóteles e Locke. A partir disso, pode-se afirmar que a linguagem é inata e é uma capacidade que se tem para adquirir as línguas.

Depois desses prolegômenos linguístico-filosóficos, mais um lapso de tempo ocorreu até que a retomada do assunto tivesse um caráter científico quando, no Século XX, Ferdinand Saussure $^{7}$ e Noam Chomsky ${ }^{8}$ lançam suas bases nas ideias de Aristóteles e Platão, respectivamente. Passa-se a seguir a examinar duas as dicotomias linguísticas que esse debate milenar enseja:

\subsection{Língua e fala}

A linguística alçou à condição de ciência pela contribuição decisiva de Ferdinand Saussure o qual, dedicando-se aos aspectos da língua, a sistematizou ao definir seu objeto e sua metodologia, criando as dicotomias "língua/fala", "significante/significado", "sincronia/diacronia" e "paradigma/sintagma". Essas dicotomias são essencialmente convencionadas, ou convencionalistas, e constituem o arcabouço de sua teoria.

Necessário destacar o recorte dicotômico "língua/fala" em aparente detrimento das demais para que a comparação com a tradição filosófica seja entendida da melhor forma e porque essa dicotomia retoma as ideias de Aristóteles quanto ao convencionalismo.

${ }^{6}$ JAPIASSÚ e MARCONDES. Ob. cit., p. 84. Empirismo é a "doutrina ou teoria do conhecimento segundo a qual todo conhecimento humano deriva, direta ou indiretamente, da experiência sensível externa ou interna. [...] O empirismo, sobretudo de Locke e Hume, demonstra que não há outra fonte do conhecimento senão a experiência e a sensação. As ideias só nascem do enfraquecimento da sensação, e não podem ser inatas."

7 SAUSSURE, Ferdinand. Curso de Linguística Geral. $7^{\text {a }}$. ed. São Paulo: Cultrix, 1975. Vale dizer que a obra foi transcrita pelos alunos do autor e publicada em 19l6, estabelecendo as bases para dar o caráter científico aos estudos de linguagem: a Linguística.

8 CHOMSKY, Noam. Estruturas Sintáticas. Portugal: Edições 70, 1980. 
Mas antes é preciso deixar claro que o objeto de estudo mais importante de Saussure está no signo linguístico, que contém a dicotomia "significante/significado", que é mental e está "depositado" na cabeça de cada indivíduo. "Significante" é a forma sonora da palavra escrita e que representa o "significado", que é um conceito ou ideia. Dizendo da forma como Saussure o definiu, o "significante" é a imagem acústica e o "significado" o seu conceito, constituindo-se aí uma arbitrariedade do signo, entendendo-se "arbitrário" como algo que "só depende da escolha, do arbítrio ou da decisão livre dos homens [, a qual se faz de maneira] injustificada ou sem motivos racionais". ${ }^{9}$ É como se fosse uma folha de papel em que um não existe sem o outro, nem o "significante" existe sem o "significado" e vice-versa. E para que se tenha significação, é preciso que haja relação entre signo e a coisa, signo e o conceito e signo e acontecimentos. Caracteriza-se assim a relação convencionalista de língua e não de linguagem.

O tempo em Saussure também foi determinante, pois os $\operatorname{signos}^{10}$ foram sendo concebidos dia a dia desde a sua origem. "Sincronia/diacronia" é mais uma das dicotomias necessária para fundamentar a não naturalidade da língua. "Sincronia" estuda os signos em um determinado tempo linguístico e se caracteriza pela sua imutabilidade, ou seja, em linhas gerais, é um estudo para compor todo o léxico ${ }^{11}$ de uma língua em um determinado momento em uma comunidade linguística. Já o termo “diacronia” estuda esses signos diacronicamente, ou seja, cronologicamente desde a sua origem, fazendo-se um estudo etimológico em um período definido pelo linguista através da descrição de uma palavra em diferentes estados de língua anteriores até remontar ao "étimo". Obviamente que, nesses termos, o signo é mutável e se altera conforme a conveniência da sociedade. ${ }^{12}$

Na prática da fala, dia a dia os signos podem se alterar e com isso a estrutura da própria língua. O termo "sincronia" é para ser entendido como estudo em que esses signos sejam imutáveis em sua relação "significante/significado". Na verdade, é um termo metodologicamente assumido para a imutabilidade, o que não acontece com "diacronia", que é um estudo cronológico e mutável por natureza. Essas duas expressões, língua e fala,

9 JAPIASSÚ, Hilton e MARCONDES, Danilo. Ob. cit., p. 15.

${ }^{10}$ Existem signos de outros tipos, mas neste tópico do artigo trata-se daquele estritamente linguístico, não necessitando de seu adjetivo para delimitá-lo como "signo linguístico".

${ }^{11}$ Entenda-se aqui como um conjunto de palavras de uma língua.

${ }^{12}$ SAUSSURE, ob. cit., passim. 
reforçam o caráter convencional da linguagem, fazendo oposição entre si e ambas compondo uma das dicotomias de Saussure e que somadas chega-se ao resultado chamado "linguagem". 13

\subsection{Competência e desempenho}

Esta segunda dicotomia também está na teoria dos estudos de linguagem. Chomsky contribui com o binômio "competência/desempenho", baseando-se em que o indivíduo tenha a capacidade inata para a linguagem, especificamente para a aquisição da língua e que é representada por uma estrutura gramatical mental capaz de produzir infinitas sentenças com um número finito de palavras e de regras. É uma capacidade genética que pessoa tem para essa aquisição. Começa a sua teoria definindo "competência" como "um conjunto de regras internalizadas que permite ao indivíduo produzir, entender e avaliar enunciados de qualquer língua, mas que é desprovido de consciência dessas regras"; quanto ao "desempenho", é a realização do que se fala, ouve, escreve ou lê e está ligado diretamente à "competência" de cada um. ${ }^{14}$

Chomsky desenvolveu muitos outros trabalhos, mas o outro mais destacado é com relação ao "Gerativismo". Ele desenvolveu uma "Gramática Universal" - "GU” - presente em todas as línguas e que tem como fundamento a dicotomia já referida; ele defende que a outra é uma gramática particular, em que a pessoa se utilizada da gramática universal e das nuances de sua própria língua. Fica claro que a "competência" está ligada à GU e é comum a todas as línguas e não se altera por nenhum motivo, mas o "desempenho" pode ser influenciado pela situação emocional com que se encontra o indivíduo. É somente para registrar o contraste que está sendo produzido pelo conhecimento que se têm das regras quando se faz uso delas. Dizendo de outra forma, Chomsky afirma que a investigação do desempenho da pessoa depende de como se "compreende a competência". Mas tudo isso são teorias que Chomsky introduziu na linguística e tem a consciência de que a "competência", seu objeto de estudo é para um falante-ouvinte ideal e que pertença a uma comunidade ideal.

13 Ibidem.

14 CHOMSKY, ob. cit., passim. 
Para o estruturalista, a língua é um sistema homogêneo, um conjunto de signos exterior aos indivíduos que deve ser estudado separado da fala. Por outro lado Chomsky em sua teoria gerativista afirma que os seres humanos apresentam uma predisposição genética que permite a aquisição da linguagem. Segundo ele, a língua é um sistema de princípios radicados na mente humana. Noam Chomsky relaciona, ainda, a aquisição da língua a termos conhecidos como: competência e desempenho, em que o primeiro é natural, ou seja, a capacidade inata para a aquisição das línguas, sendo o segundo a sua "performance".

Assim como Platão e Aristóteles, Crátilo e Hermógenes e Leibniz e Locke têm na mesma fonte de discussão a "linguagem" e a "língua" como objetos bem definidos, Saussure e Chomsky também. O primeiro é estruturalista e estuda a "língua" e o outro, também estruturalista, mas do nível mental-cognitivo, estuda a "linguagem". Esses dois teóricos do Século XX compõem, nesta ordem, as duas revoluções linguísticas mais relevantes da área da linguagem.

Mas os estudos linguísticos não param por aqui. Outra obra que trata do assunto é "Tabula Rasa", de Steven Pinker ${ }^{15}$ - homônima ao debate anteriormente citado, portanto -. No prefácio do livro, ${ }^{16}$ uma frase interrogativa já induz os leitores para um pressuposto da certeza: “[...] Ainda existe gente que acredita que a mente é uma tabula rasa?” e mais adiante:

Esse argumento contra a tabula rasa foi exposto energicamente por Gottfried Wilhelm Leibniz (1646-1716) em uma réplica a Locke. Leibniz repetiu o lema do empirismo: "Não existe nada no intelecto que não estivesse primeiro nos sentidos", e acrescentou: "exceto o próprio intelecto". Alguma coisa na mente tem de ser inata, se ela é apenas o mecanismo responsável pela aprendizado. (...) Alguma coisa tem de inferir o conteúdo de uma sentença em vez de papaguear as palavras exatas em resposta. ${ }^{17}$

Essa discussão dicotômica permite fazer a relação do "alguma coisa na mente tem de ser inata" com o "inferir o conteúdo de uma sentença", em que a primeira frase se refere à linguagem como capacidade para a comunicação, e a segunda, o mecanismo sentença como uma estrutura morfossintático-semântica da língua.

15 PINKER, Steven. Tabula Rasa: a negação contemporânea da natureza humana ; tradução Laura Teixeira Motta. $2^{\mathrm{a}}$. Reimpressão. São Paulo: Companhia das Letras, 2008.

16 PINKER, ob. cit., p. 9.

17 Ibidem, p. 59. 
$\mathrm{O}$ leitor pode estar se perguntando "O que tem a ver essas dicotomias linguísticas com a obra 'Antígona' e principalmente com outras que são jurídicas?" O ponto de convergência principal está relação social da "arbitrariedade", ou seja, enquanto Creonte arbitra em relação às leis dos homens, a língua arbitra na relação dos nomes com as coisas, relação que ficará mais clara ao se examinar os dois problemas dicotômicos do mundo jurídico:

\section{DUAS DICOTOMIAS JURÍDICAS}

\subsection{Direito natural e direito positivo}

A contraposição ancestral essas duas concepções do direito pode ser resumida no antológico diálogo entre Antígona e Creonte. Isso porque a fala da primeira deixa transparecer seu respeito pelas divindades e suas obras - dentre elas, o direito, o qual é visto pela personagem como fruto da vontade de Zeus ou da Justiça -; por sua vez, o discurso de Creonte é pela supremacia daquilo que foi decidido como lei pelos homens aqui na terra, sendo por hora irrelevante o fato de o édito em debate ser de sua própria autoria. Vejamos o trecho do drama: ${ }^{18}$

Guarda: [...] ela, ao avistar o cadáver desnudado [...] presta honras ao cadáver com um tríplice libação.

Creonte: $\mathrm{E}$ tu, tu que voltas o rosto para o chão, afirma ou negas o teu ato?

Antígona: Afirmo que o pratiquei, e não nego que o fizesse.

Creonte: [...] E agora tu diz-me, sem demora, em poucas palavras: sabias que fora proclamado um édito que proibia tal ação?

Antígona: Sabia. Como não havia de sabê-lo? Era público.

Creonte: E ousaste, então, tripudiar sobre estas leis?

Antígona: É que essas não foi Zeus que as promulgou, nem a Justiça, que coabita com os deus infernais, estabeleceu tais leis para os homens. E eu entendi que os teus éditos não tinham tal poder, que um mortal pudesse sobrelevar os preceitos, não escritos, mas imutáveis dos deuses. [...]

${ }^{18}$ SÓFOCLES. Antígona. Ed. Fundação Calouste Gulbenkian. 10ª ed., 2012, p. 67. 
Pode-se afirmar que esse diálogo vem se repetindo por cerca de dois milênios em diferentes roupagens e antíteses: na antiguidade, "natureza/normas"; na idade média, "direito divino/direito humano"; na modernidade, "razão individual/direito positivo". Embora variassem os fundamentos - natureza, religião e razão, nos casos citados -, se estava sempre a falar de algo anterior às normas criadas pelo homem; sempre era algo "natural" que se sobrepunha ao direito escrito, o qual se fortalecia se "de acordo" com a fundamentação vista como essencial ou merecia perecer se a contrariasse. ${ }^{19}$ É nesses termos que, ao rejeitar a lei do mortal Creonte, Antígona defende o que afirma ser direito divino imutável desde sempre ${ }^{20}$ sustentando a supremacia do direito natural sobre o direito positivo, sendo este o "sistema de normas" forjadas pelo homem que perfaz a totalidade do direito abstraído de "valorações éticas" e de "realidades sociais". ${ }^{21}$ Em suma: o direito natural é algo além a ser descoberto, imutável e impregnado de justiça, enquanto o direito positivo é conjunto de normas jurídicas imperfeitas criadas pelo homem em sua busca pela justiça.

Estabelecida uma conceituação básica de direito "natural" e "positivo" - aqui sem as nuances, aspectos e complexidades que se sabe neles existir -, passa-se a examinar em poucas palavras seu embate histórico e constante, o qual tem acompanhado o andar da humanidade com movimentos em direção a uma ou outra das duas concepções.

É assim que H. Rommen falou em "eterno retorno ao direito natural", ao que A. Ollero Tassara respondeu com a "eterna rotina do positivismo jurídico". ${ }^{22}$ Com o protagonismo de um ou outro conceito, essa dicotomia permanece. Enquanto o positivismo jurídico teve no Século XIX seu "momento culminante", ${ }^{23}$ há cerca de cinco décadas "é quase de bom tom rechaçar e até condenar o positivismo jurídico", ${ }^{24}$ por sua vez, desde o pós-guerra do Século

19 RADBRUCH, Gustav. Filosofia do direito. Tradução e prefácios: L. Cabral de Moncada. Coimbra. 6. ed. rev.e acrescida dos últimos pensamentos do autor. Reimpressão. Coimbra: Ed. Armênio Amado, 1997, p. 61-2.

20 SÓFOCLES, ob. cit., p. 67.

${ }^{21}$ LATORRE, Angel. Introdução ao direito. Trad. Dr. Manuel de Alarcão. 5. Reimpressão. Ed. Almedina. Coimbra, 2002, p. 151.

22 ROMMEN, H. e TASSARA, A. Ollero apud VIGO, Rodolfo L. Iusnaturalismo vs. Iuspositivismo: um alegato iusnaturalista. In: CABANILLAS, Renato Rabbi-Baldi. (Coord.) Las razones del derecho natural: perspectivas teóricas y metodológicas ante la crisis del positivismo jurídico. 2. ed. corr. estructurada y ampliada. Buenos Aires: Editorial Ábaco de Rodolfo Depalma, 2008, p. 221.

23 LATORRE, ob. cit., p. 153.

24 HOERSTER, N. apud VIGO, Rodolfo L, ob. cit., p. 223. 
XX, o jusnaturalismo "experimentou um renascimento espetacular" após parecer "morto e enterrado" (!) no auge de seu antagonista. ${ }^{25}$

Interessante notícia de março deste ano dá conta do rompimento de tradições funerárias do Afeganistão enquanto mulheres carregaram o esquife de uma jovem que fora morta por pedradas e agressões e teve seu corpo incendiado. Essa violência toda teve como estopim uma suposta heresia da jovem, a qual teria queimado uma cópia do Alcorão; no entanto, não havia prova alguma de que tal tivesse mesmo ocorrido. A analogia possível com a atitude de Antígona é o fato de que o costume local manda que apenas homens carreguem um caixão, tradição enfrentada por ativistas em respeito e protesto pelo ocorrido, certamente fundamentando o direito da morta de ser homenageada por suas iguais. "As mulheres choravam e gritavam 'queremos justiça para Farkhunda'." Ainda há forte discriminação e grande violência contra a mulher no Afeganistão, mas o ataque em questão, pela sua virulência e despropósito, motivou o protesto. ${ }^{26}$

Cabe agora questionar se essa oposição entre natural e positivo não seria também uma relação de complementaridade entre ambos. A respeito, cabe lembrar as lições de Andrés Ollero sobre um almejado "jusnaturalismo crítico". Para o autor, do mesmo modo que inexiste uma "positividade instantânea" - mas sim "um contínuo processo de positivação", da criação da lei até a coisa julgada -, tampouco existe um direito natural pronto e acabado, cabendo ao jurídico estabelecer um "contínuo esforço de fidelidade às exigências da natureza humana, as quais estimulem criticamente esse mesmo processo de positivação". ${ }^{27}$ Assim, pode-se afirmar que o direito natural e o direito positivo dialogam entre si para que se chegue ao melhor de ambos. Desse modo, a fala entre Antígona e Creonte foi parte desse debate inacabável, o qual permanece.

\subsection{Direito universal e direito local}

25 LATORRE, ob. cit., p. 180.

${ }^{26}$ ATIVISTAS afegãs rompem tradição e carregam caixão de mulher linchada. BBC Brasil. 22 mar. 2015. Disponível em:

http://www.bbc.co.uk/portuguese/noticias/2015/03/150322_mulheres_enterro_afeganistao_cc > Acessado em 3 mai. 2015.

${ }_{27}$ OLLERO, Andrés. España: limites del normativismo a la luz de la jurisprudencia constitucional sobre igualdad. In: CABANILLAS, Renato Rabbi-Baldi. (Coord.). Las razones del derecho natural: perspectivas teóricas y metodológicas ante la crisis del positivismo jurídico. 2. ed. corregida, reestructurada y ampliada. Buenos Aires: Editorial Ábaco de Rodolfo Depalma, 2008, p. 458. 
Outra interessante dicotomia jurídica é aquela que se faz entre direitos supostamente "universais", extensivos a todas as civilizações, e direitos "locais", restritos a certa(s) comunidade(s). Em verdade, inicia-se por dizer que esse debate jurídico é apenas parte de um contexto muito mais amplo correspondente à polêmica que se faz entre "liberalistas", que sustentam que diferenças culturais dizem respeito ao "âmbito privado e não ao público", ${ }^{28} \mathrm{e}$ "comunitaristas", adeptos da teoria de que cada indivíduo deve permanecer "integrado na cultura de sua comunidade, [vinculado assim a] suas raízes culturais representadas por uma história, valores e relações", as quais podem integrá-lo e oferecer "um sentido à sua existência". ${ }^{29}$ Assim, em simplificação arriscada, pode-se dizer que os primeiros priorizam o indivíduo e sua liberdade; o segundo, a comunidade como um todo. Essa contraposição acarreta muitos efeitos jurídicos, como principalmente é o caso da "Declaração (Universal?) dos Direitos Humanos" de 1948 e seu (real?) alcance a povos cujos valores pouco se aproximam daqueles que foram determinantes para decidir aquele documento e seu alcance. Para bem ilustrar essa polêmica cabe transcrever interessante trecho da obra de Heiner Bielefeldt: ${ }^{30}$

\begin{abstract}
'Direitos humanos: um conceito ocidental com aplicabilidade restrita' é o título programático, mas também polêmico, do ensaio publicado por Adamatia Pollis e Peter Schwab (1979), dois dos mais radicais representantes da crítica de relativização cultural aos direitos humanos. [... Há uma ideia de] caráter primordialmente ocidental dos direitos humanos e sua aplicabilidade restrita em relação a outras culturas [, considerando-os] genuína expressão da forma de viver e da cosmovisão ocidentais que, como se diz, contradizem em sua base as culturas teocêntrica ou cosmocêntrica, vigentes fora da Europa e da América do Norte. [...] Talvez mais importante seja a objeção de que os direitos humanos sejam ligados aos pressupostos culturais e filosóficos de tradição ocidental, por terem surgido nesse contexto. $[\ldots]$
\end{abstract}

${ }^{28}$ GÓMEZ, Ambrosio Velasco. Multiculturalismo y republicanismo. In: Ética y diversidad cultural. León Olivé (Org.). 2. ed. Ed. Fondo de Cultura Economica FCE, UNAM. México, 2004, p. 325.

29 JAPIASSÚ, Hilton e MARCONDES, Danilo. Dicionário básico de filosofia. 4. ed. atual. Rio de Janeiro. Editora Zahar, 2006, p. 50. A teoria foi desenvolvida primordialmente nos Estados Unidos da América, principalmente por Michael Sandel, Charles Taylor e Alasdair MacIntyre.

${ }^{30}$ BIELEFELDT, Heiner. Filosofia dos direitos humanos: fundamentos de um ethos de liberdade universal. São Leopoldo: Ed. Unisinos, 2000, p. 141. 
Certamente, não é neste pequeno espaço que se poderá chegar a uma conclusão sobre essa oposição entre "direito universal x direito comunitário". Pretende-se aqui tão somente apresentar de maneira suficientemente clara a questão, a qual enseja problemas jurídicos concretos também cada vez mais próximos de nossa realidade, principalmente quando o Brasil se torna destino de grandes levas de imigrantes ${ }^{31}$ que certamente trarão consigo aqueles "valores e raízes" de que falam os comunitaristas.

Um problema muito grave se verificou há pouco no Rio de Janeiro, onde um grupo de comerciantes é acusado de aliciamento de chineses para trabalho em regime análogo ao de escravo, sem salário e com prestação de serviços sem um só dia de folga. Os aliciadores são compatriotas que certamente se prevalecem de sua condição de "semelhante" para convencer pessoas com sua identidade cultural a trabalhar em suas empresas no Brasil, sem dar conta das condições desumanas do ambiente de trabalho oferecido e da dívida que o aliciado contrai com sua vinda ao país. Desde 2013 o Ministério Público do Trabalho encaminhou três inquéritos à Justiça Federal dando conta desses lamentáveis fatos. ${ }^{32} \mathrm{O}$ que deve ser observado aqui é a contraposição entre os valores culturais e o direito brasileiro, o qual indiscutivelmente deve ser respeitado no território do país, sejam os indivíduos da origem cultural que o forem.

Aproveita-se o ensejo para uma rápida lembrança de uma outra dicotomia jurídica, a qual permite o agrupamento de campos jurídicos autônomos em duas grandes áreas: o direito "público" e o "privado", caracterizando-se o primeiro pelo "exercício do poder do Estado" por "imperium", enquanto o ramo privado "regula as relações entre particulares". ${ }^{33} \mathrm{O}$ problema tratado no parágrafo anterior diz respeito ao direito do trabalho, ramo jurídico que não pode ser facilmente catalogado em um desses dois campos. Isso porque estão sob o âmbito da seara laboral: as relações de emprego individuais entre trabalhadores e empregadores; a regulação de "condições de trabalho em sentido amplo", abrangendo normas

${ }^{31}$ NOVA onda de imigrantes haitianos causa superlotação em paróquia. Folha de São Paulo. Thais Bilenky. São Paulo. 20 mai. 2015. Disponível em: < http://www1.folha.uol.com.br/cotidiano/2015/o5/1631279-nova-onda-de-imigrantes-haitianoscausa-superlotacao-em-paroquia.shtml > Acessado em 8 jul. 2015.

${ }^{2}$ MINISTÉRIO público do trabalho investiga máfia que alicia chineses para trabalho escravo. O Globo. G1 Rio. Disponível em: < http://oglobo.globo.com/rio/ministerio-publico-do-trabalhoinvestiga-mafia-que-alicia-chineses-para-trabalho-escravo-15843730 > Acessado em 3. Mai. 2015. 33 LATORRE, Angel. Introdução ao direito. Trad. Dr. Manuel de Alarcão. 5. Reimpressão. Ed. Almedina. Coimbra, 2002, p. 208-10. Ressalva-se que hoje é pacífico que não há separação radical entre ambos os ramos. 
de saúde e segurança do meio ambiente laboral; e as relações entre sindicatos de empresas e sindicatos de trabalhadores entre si. Cada um desses subcampos se encaixaria melhor respectivamente - no direito privado, no direito público e em um misto de ambos. ${ }^{34}$ Sendo assim, tratando o caso em exame de "condições do trabalho [, aqui se fala de direito] de natureza pública”, envolvendo matéria a prevenção e a reparação de riscos sociais. ${ }^{35}$

Frente à globalização e ao trânsito de povos cada vez mais marcante, tudo aliado à revolução nas comunicações que a "internet" vem produzindo a passos largos, a polêmica "direito universal/direito local" tende a aumentar cada vez mais, pois os conflitos entre normas distintas deve se intensificar. Caberá ao direito resolver o quanto possível os impasses constantes que enfrentará.

\section{4. COTEJAMENTO DICOTÔMICO \\ LINGUÍSTICO-JURÍDICO:} ARBITRARIEDADE E MUTABILIDADE

\subsection{Arbitrariedade}

Na linguística, o signo é arbitrário porque não há relação entre o significante e o seu significado; quem o convenciona é a própria comunidade linguística, o que se justifica pela quantidade de línguas existentes pelo mundo. Um exemplo para ilustrar é a palavra "casa" correspondente a "house" em inglês, o que basta para se inferir que existe na concepção de língua um autoritarismo na nomeação das coisas - o qual correspondente no direito à inferência e que o autoritarismo de Creonte fere as relações sociais em relação ao objetivo comum. Parece então que a arbitrariedade linguística é necessária para a comunicação sem que haja prejuízo social, enquanto o arbítrio no direito parece provocar alguma perda.

De fato, sob o aspecto jurídico mais amplo, "poder arbitrário é um poder ilegal, independente das leis em virtude das quais ele se exerce" ${ }^{36}$ definição essa aplicável a questões de direito público. Nesses termos, pergunta-se se a decisão de Creonte teria sido "arbitraria" sob o ângulo jurídico; e se o foi, o foi em relação a quê. A isso se pode responder que, de acordo com o que se viu acima, admitindo-se a existência e o protagonismo do

34 RAMAlHO, Maria do Rosário Paula. Da autonomia dogmática do direito do trabalho. Coimbra. Ed. Almedina, 2000, p. 50.

35 RAMALHO, ob. cit., p. 52.

${ }^{36}$ JAPIASSÚ e MARCONDES, ob. cit., p. 15. 
"direito natural", sem dúvida que a fala de Creonte foi arbitrária, uma vez que contrariou leis "de Zeus" ou "da Justiça"; ${ }^{37}$ por outro lado, admitindo-se a prevalência do direito positivo, o édito promulgado por Creonte só poderia ser reputado arbitrário se in casu fossem desatendidos os trâmites legais daquele Reino para criação dessa norma em discussão; isso porque, se naquele tempo e local foi legal o procedimento de criação da lei polêmico, nada tem ela de arbitrário.

\subsection{Mutabilidade}

$\mathrm{Na}$ linguística, o estudo diacrônico permite visibilizar as constantes alterações dos signos adequando-os à necessidade de melhor se comunicar. Por exemplo, a palavra ‘implicar' é transitiva direta (implicar algo, logicamente), mas o seu uso na sociedade, em função de a língua portuguesa ser analítica, introduziu a preposição ‘em’ (implicar em algo); outro exemplo é a palavra 'você', que sofreu redução por apócope da expressão original 'Vossa Mercê', que é um pronome de tratamento e como tal necessita flexionar os verbos na terceira pessoa. Isso provocou uma mudança da flexão verbal na língua portuguesa, tanto no Brasil como em Portugal: 'você' é um pronome de segunda pessoa quando é utilizado com a pessoa com quem se fala, mas que flexiona o verbo na terceira porque a sua origem no pronome de tratamento a exige. A mutabilidade foi provocada de forma natural pela prática da fala, mas convencionada pelo meio. Se o indivíduo da comunidade a qual ele pertence não estiver atualizado em relação às alterações, será penalizado com sanções discriminatórias e preconceituosas socialmente. Quanto à mutabilidade jurídica, a penalidade será outra. Dito de outra forma, enquanto a arbitrariedade linguística é do social para o indivíduo, a jurídica é do indivíduo para o social.

No campo jurídico, o "direito positivo" é arbitrário, podendo também ser arbitrariamente mutável, ${ }^{38}$ o que pode ocorrer de duas formas: ou ocorre uma quebra total da ordem jurídica de uma Nação, trazendo à tona uma nova Constituição alterando totalmente as normas vigentes em seu território, ou se segue os trâmites legais previstos nas próprias

37 SÓFOCLES, ob. cit., p. 67.

${ }^{38}$ Como consta da primeira página da obra máxima do positivismo moderno, à "Teoria Pura do Direito [...] não lhe importa a questão de saber como deve ser o direito, ou como ele deve ser feito" entendendo-se aqui "feito" como também "refeito", é claro - In KELSEN, Hans. Teoria Pura do Direito. Trad. João Baptista Machado. $7^{\mathrm{a}}$ ed. Ed. Martins Fontes. São Paulo, 2006, p. 1. 
normas para alterá-las, o que ocorre, por exemplo, em emendas constitucionais, promulgação de novos códigos de lei, etc. Em qualquer caso, também o arbitrário e o mutável estão presentes no direito positivo, o que remete ao "convencionalismo", linguístico, pelo qual a palavra é "cunhada" para representar significados ou fazer referência a coisas. Por outro lado, observa-se que, na linguística, o que é "natural" é o significado do signo, que independe da língua, ao passo que, sob a ótica jurídica, o "direito natural" é algo também visto como perene.

\section{CONSIDERAÇÕES FINAIS: ATUALIDADE DA “ARBITRARIEDADE" LINGUÍSTICA E JURÍDICA NA FALA DE CREONTE}

Tratando-se das dicotomias apresentadas, nada é tão simples assim. Vive-se hoje na Europa flagrante tensão entre os costumes de imigrantes e o direito local. Em França, permanece a polêmica sobre muçulmanas terem ou não direito de vestir seu véu característico tomou o país. A respeito, Jean-Marc Trigeaud teceu pesada crítica à normatização a respeito em artigo que remete justamente à peça de Sófocles que serve como mote para esse estudo: "França: o complexo de Creonte. Governar os costumes ou censurar o Islã e as outras religiões" ${ }^{39}$ Para o autor, "quando um magistrado europeu se permite interpretar e emitir juízo de valor sobre o rito religioso islâmico [sem] se perguntar se não viola o princípio elementar da tolerância", não se está fazendo justiça. ${ }^{40}$ Em verdade, é injustiça que assim se faz, da mesma forma que Creonte a fez ao intrometer-se na forma de atos funerários. Conclui o articulista que "assim começa o despotismo por parte do direito [, quando] o legislador tem a imprudência de querer tudo regular". ${ }^{41}$

Estaria o autor exagerando em sua posição? Poderia o jurídico ser tão arbitrário quanto o signo linguístico, abdicando-se de uma relação entre "o real e a lei"? Estaria o direito extrapolando tanto seus limites de modo a chegar-se ao despotismo? Por outro lado, se uma lei gramatical é violada, há sanção como no direito na forma de preconceito linguístico? Não

39 TRIGEAUD, Jean-Marc. Francia: El complejo de Creonte. Gobernar las costumbres o censurar el Islam y las otras religiones. In: (Coord.) Las razones del derecho natural: perspectivas teóricas y metodológicas ante la crisis del positivismo jurídico. 2. ed. corr. estructurada y ampliada. Buenos Aires: Editorial Ábaco de Rodolfo Depalma, 2008, p. 477.

40 TRIGEAUD, ob. cit., p. 479.

${ }^{41}$ Ibidem, p. 481-2. 
é possível por hora responder a essas questões. O que não há como negar é que, de uma forma ou de outra, o debate entre Antígona e Creonte permanece atual.

\section{REFERÊNCIAS BIBLIOGRÁFICAS}

ALVES, Elizete Lanzoni. A interdisciplinaridade no ensino jurídico: construção de uma proposta pedagógica. In: $\mathbf{O}$ ensino jurídico interdisciplinar: um novo horizonte para o direito. MONDARDO, Dilsa, ALVES, Elizete Lanzoni e SANTOS, Sidney Francisco Reis dos (Orgs.). Florianópolis. OAB/SC Editora, 2005

ATIVISTAS afegãs rompem tradição e carregam caixão de mulher linchada. BBC Brasil. 22 mar. 2015. Disponível em: < http://www.bbc.co.uk/portuguese/noticias/2015/03/150322_mulheres_enterro_afeganistao_cc $>$ Acessado em 3 mai. 2015.

BIELEFELDT, Heiner. Filosofia dos direitos humanos: fundamentos de um ethos de liberdade universal. São Leopoldo: Ed. Unisinos, 2000.

CHOMSKY, Noam. Estruturas Sintáticas. Portugal: Edições 70, 1980.

GÓMEZ, Ambrosio Velasco. Multiculturalismo y republicanismo. In: Ética y diversidad cultural. León Olivé (Org.). 2. ed. Ed. Fondo de Cultura Economica FCE, UNAM. México, 2004, p. 320-40.

JAPIASSÚ, Hilton e MARCONDES, Danilo. Dicionário básico de filosofia. 4. ed. atual. Rio de Janeiro. Editora Zahar, 2006.

KELSEN, Hans. Teoria Pura do Direito. Trad. João Baptista Machado. $7^{\text {a }}$ ed. Ed. Martins Fontes. São Paulo, 2006.

LATORRE, Angel. Introdução ao direito. Trad. Dr. Manuel de Alarcão. 5. Reimpressão. Ed. Almedina. Coimbra, 2002.

MINISTÉRIO público do trabalho investiga máfia que alicia chineses para trabalho escravo. O Globo. G1 Rio. Disponível em: < http://oglobo.globo.com/rio/ministerio-publico-dotrabalho-investiga-mafia-que-alicia-chineses-para-trabalho-escravo-15843730 > Acessado em 3. Mai. 2015.

NOVA onda de imigrantes haitianos causa superlotação em paróquia. Folha de São Paulo. Thais Bilenky. São Paulo. 20 mai. 2015. Disponível em: < 
http://www1.folha.uol.com.br/cotidiano/2015/05/1631279-nova-onda-de-imigranteshaitianos-causa-superlotacao-em-paroquia.shtml> Acessado em 8 jul. 2015.

OLLERO, Andrés. España: limites del normativismo a la luz de la jurisprudencia constitucional sobre igualdad. In: CABANILLAS, Renato Rabbi-Baldi. (Coord.). Las razones del derecho natural: perspectivas teóricas y metodológicas ante la crisis del positivismo jurídico. 2. ed. corregida, reestructurada y ampliada. Buenos Aires: Editorial Ábaco de Rodolfo Depalma, 2008, p. 441-458.

PINKER, Steven. Tabula Rasa: a negação contemporânea da natureza humana ; tradução Laura Teixeira Motta. 2a . Reimpressão. São Paulo: Companhia das Letras, 2008.

PLATÃO. Diálogos VI: Crátilo, Cármides, Láques, Ion, Menexeno. São Paulo: Edipro, 2010.

RADBRUCH, Gustav. Filosofia do direito. Tradução e prefácios: L. Cabral de Moncada. Coimbra. 6. ed. rev.e acrescida dos últimos pensamentos do autor. Reimpressão. Coimbra: Ed. Armênio Amado, 1997.

RAMALHO, Maria do Rosário Paula. Da autonomia dogmática do direito do trabalho. Coimbra. Ed. Almedina, 2000.

SAUSSURE, Ferdinand. Curso de Linguística Geral. 7ª . ed. São Paulo: Cultrix, 1975.

SÓFOCLES. Antígona. Ed. Fundação Calouste Gulbenkian. 10ª ed., 2012.

TRIGEAUD, Jean-Marc. Francia: El complejo de Creonte. Gobernar las costumbres o censurar el Islam y las otras religiones. In: (Coord.) Las razones del derecho natural: perspectivas teóricas y metodológicas ante la crisis del positivismo jurídico. 2. ed. corr. estructurada y ampliada. Buenos Aires: Editorial Ábaco de Rodolfo Depalma, 2008, p. 477-483.

VIGO, Rodolfo L. Iusnaturalismo vs. Iuspositivismo: um alegato iusnaturalista. In: CABANILLAS, Renato Rabbi-Baldi. (Coord.) Las razones del derecho natural: perspectivas teóricas y metodológicas ante la crisis del positivismo jurídico. 2. ed. corr. estructurada y ampliada. Buenos Aires: Editorial Ábaco de Rodolfo Depalma, 2008, p. 221239.

(Artigo submetido em 12/07/2015, aceito em 28/07/2015). 